\title{
Pendidikan agama islam non formal dalam setting inklusif bagi anak dengan hambatan pendengaran
}

\author{
Bayu Pamungkas ${ }^{{ }^{*}}$, Zaenal Alimin ${ }^{2}$ \\ ${ }^{1}$ Universitas Negeri Yogyakarta \\ ${ }^{2}$ Universitas Pendidikan Indonesia. \\ * Corresponding Author. E-mail: bayu.pamungkas@uny.ac.id, Telp: +6285642460179
}

\begin{abstract}
Abstrak: Penelitian ini bertujuan untuk menggambarkan pelaksanaan pendidikan agama Islam bagi anak dengan hambatan pendengaran di Masjid Khoiru Ummah Semarang. Jenis penelitian ini adalah penelitian kualitatif deskriptif menggunakan desain studi kasus. Teknik observasi partisipatif dan wawancara semi terstruktur terhadap subjek penelitian yakni tiga pembimbing anak dengan hambatan pendengaran dan tiga anak dengan hambatan pendengaran digunakan untuk pengumpulan data. Dari penelitian ini diperoleh data hasil penelitian sebagai berikut: (1) dalam proses pendidikan terdapat lima kegiatan pendidikan agama. Seluruh pelaksanaan kegiatan melibatkan masyarakat umum, BISINDO digunakan sebagai sistem komunikasi utamanya selain penggunaan Komunikasi total, Contextual Teaching and Learning diterapkan sebagai metode pembelajaran, serta materi pendidikan agama yang diajarkan disesuaikam; (2) dalam setting kegiatan terdapat tiga setting yang disesuaikan dengan kompleksitas materi yang diajarkan; (3) profil anak dengan hambatan pendengaran yang mengikuti pendidikan agama adalah anak dengan hambatan pendengaran usia remaja. Mereka juga mengajak anak dengan hambatan pendengaran lain untuk ikut bergabung; (4) terkait profil pembimbing anak dengan hambatan pendengaran, mereka adalah masyarakat yang sukarela membimbing anak dengan hambatan pendengaran yang kemudian mengikuti pelatihan intensif; (5) hasil pendidikan agama menunjukkan bahwa anak dengan hambatan pendengaran memiliki kefahaman beragama, ketaatan dalam beribadah dan hubungan bermasyarakat yang baik.
\end{abstract}

Kata Kunci: Pendidikan Agama Islam, Non Formal, Inklusif, Anak dengan Hambatan Pendengaran

\section{Non-formal islamic religious education in an inclusive setting for children with hearing impairment}

\begin{abstract}
The research aims to describe the implementation of Islamic religious education for children with hearing impairment in Khoiru Ummah Mosque Semarang. The kind of this research is descriptive-qualitative research with case study design. Participatory observation and semi structured interview with three supervisors and three children with hearing impairment as the subjects of this research use to data collected. The result of this research are: (1) in terms of process of education there are five religious education activities. All of the activities involved the public in their implementations, where BISINDO as a primary communication system besides Totally Communication used, Contextual Teaching and Learning is the method applied, materials of religious education adjusted; (2) with respect to the setting, there are three setting that adjusted to the material complexity in many activities; (3) in terms of children with hearing impairment profile who attend religious education are children with hearing impairment as young people. They also invite the other hearing impairment children to join; (4) regarding the profile of children with hearing impairment supervisors, they are community who voluntarily guide children with hearing impairment who then take intensive training; and (5) as regards religious education results, children with hearing impairment have religious understanding, observance in worship and good community relations.
\end{abstract}

Keywords: Islamic Religious Education, Non Formal, Inklusif, Children with Heraring Impairment

\section{PENDAHULUAN}

Salah satu tujuan pendidikan adalah membangun religiusitas. Dalam hal ini pendidikan agama berkedudukan sebagai bagian integral dari sistem pendidikan nasional. Undang-Undang Sistem Pendidikan Nasional No. 20 tahun 2003 Pasal 13 Butir a menyatakan bahwa "Setiap peserta didik 


\title{
J PK (J urnal Pendidikan Khusus), 16 (1), 2020 - 20
}

\author{
Bayu Pamungkas, Zaenal Alimin
}

berhak mendapatkan pendidikan agama sesuai dengan agama yang dianutnya dan diajarkan oleh pendidik seagama" (UU Sisdiknas, 2003).

Subakti (2011, hlm. 5) menjelaskan bahwa bahwa dalam pendidikan agama, pendidikan bukan hanya ditekankan pada penjelasan materi, sebuah pelajaran teoritis yang terdiri dari kegiatan membaca buku dan menghafalnya, tetapi pengamalan atau penghayatan terhadap nilai agama menjadi hal yang paling ditekankan dalam sebuah pendidikan agama tersebut. Menambahakan hal tersebut (Wibowo, 2011, hlm. 11) menjelaskan bahwa sebagai upaya memanusiakan diri setiap manusia diperlukan cara mendidik yang tepat dan pendidikan agama merupakan salah satu cara yang tepat tersebut.

Pendidikan yang lebih luas dapat dapat berlangsung dimana saja termasuk dalam keluarga dan lingkungan masyarakat, bukan hanya identik dengan kegiatan belajar mengajar formal di sekolah. Semua potensi yang ada di keluarga dan masyarakat akan dapat menjadi sebuah media dan sarana pendidikan. Hal tersebutlah yang dapat menciptakan suasana yang kondusif untuk membangun masyarakat belajar (Sunarti, 2012, hlm. 30).

Lebih lanjut Sunarti (2012, hlm. 40) menjelaskan bahwa pendidikan non formal diperlukan untuk menjadi alternatif solusi dalam memecahkan berbagai masalah pendidikan. Peran serta masyarakat secara lebih luas diperlukan dengan cara melibatkan masyarakat untuk memahami program-program dalam dunia pendidikan. Melalui cara tersebut diharapkan masyarakat dapat lebih terdorong untuk turut membantu terlaksananya program-program pendidikan tersebut secara maksimal.

Pendidikan formal maupun non formal harus dilaksanakan secara menyeluruh dan merata kepada semua warga negara tidak terkecuali kepada anak-anak berkebutuhan khusus. Sebagai warga negara, anak berkebutuhan khusus pun memiliki hak yang sama untuk memperoleh pendidikan. Undang-Undang Sistem Pendidikan Nasional No. 20 tahun 2003 Pasal 32 Butir a menjelaskan bahwa "Pendidikan Khusus merupakan pendidikan bagi peserta didik yang memiliki tingkat kesulitan dalam mengikuti proses pembelajaran karena kelainan fisik, emosional, mental, sosial, dan/atau memiliki potensi kecerdasan dan bakat istimewa” (UU Sisdiknas, 2003).

Berdasarkan hal tersebut, Wibowo (2011, hlm. 12) menambahkan bahwa wujud kontribusi program pendidikan dalam rangka peningkatan kepribadian anak berkebutuhan khusus adalah dengan memberikan pendidikan agama bagi mereka. Utamanya melalui pendidikan agama kepribadian anak berkebutuhan khusus dapat terbentuk. Pendidikan agama dapat membentuk mentalitas iman dalam diri anak berkebutuhan khusus melalui pengajaran dan penghayatan materi yang diajarkan.

Salah satu anak berkebutuhan khusus adalah anak dengan hambatan pendengaran. Somantri (2007, hlm. 24) menjelaskan bahwa anak dengan hambatan pendengaran adalah anak yang memiliki hambatan berupa ketidak berfungsian organ pendengaran sehingga mengakibatkan terbatasnya kemampuan mendengar. Keterbatasan kemampuan mendengar tersebut mengakibatkan anak dengan hambatan pendengaran memiliki keterbatasan informasi dan pengalaman yang berhubungan dengan hal-hal auditif. Secara kognitif anak dengan hambatan pendengaran memiliki kemampuan yang sama dengan anak pada umumnya, namun secara perkembangannya kemampuan kognitif tersebut tidak diimbangi dengan kemampuan berbahasanya dan minimnya perolehan informasi, sehingga mengakibatkan terhambatnya proses pencapaian pengetahuan secara lebih luas yang lebih lanjut akan juga mempengaruhi perkembangan kognitifnya.

Strategi dan metode khusus diperlukan untuk memberikan pendidikan agama yang disesuaikan keterbatasan dan hambatan anak dengan hambatan pendengaran. Fakta di lapangan menunjukkan bahwa dalam pelaksanaan pendidikan agama bagi anak dengan hambatan pendengaran di Sekolah Luar Biasa masih terdapat beberapa hambatan. Setidaknya terdapat dua hambatan selama pelaksanaan pendidikan agama di Sekolah Luar Biasa, yakni hambatan terkait rendahnya kualitas dan kurang optimalnya kompetensi guru dan hambatan dalam perencanaan yakni kurang maksimalnya metode yang digunakan untuk mengakomodir kebutuhan siswa selama proses pembelajaran (Wibowo, 2011, hlm. 15).

Masalah lain yang ditemukan dalam pelaksanaan pendidikan agama bagi anak dengan hambatan pendengaran adalah kegaiatan pendidikan agama di masyarakat secraa umum belum mampu memfasilitasi kebutuhan anak dengan hambatan pendengaran. Karena ketidakmampuan anak dengan hambatan pendengaran memahami bahasa penceramah / ustadz, terkadang kehadiran mereka pada kegiatan keagamaan tersebut menjadi hanya sekedar duduk menghadiri dan tidak dapat menangkap materi dan pesan dari ajaran agama yang disampaikan. Selain itu masalah yang juga ditemukan di 


\title{
J PK (J urnal Pendidikan Khusus), 16 (1), 2020 - 21
}

\author{
Bayu Pamungkas, Zaenal Alimin
}

lapangan adalah banyak dari anak dengan hambatan pendengaran belum memiliki pengetahuan yang komprehensif terhadap ketuhanan dan keimanan sebagai sebuah konsep dasar dalam agama. Pada beberapa kesempatan banyak dikalangan anak dengan hambatan pendengaran menyampaikan bahwa Tuhan ada 5, 7, 10 dan seterusnya ketika mereka ditanya tentang konsep ketuhanan. Hal tersebut didasarkan pada asumsi mereka bahwa Tuhan merupakan dzat yang terpisah (Tuhan yang menciptakan makhluk hidup berbeda dengan Tuhan yang memberikan rezeki, menurunkan hujan dan lain sebagainya) dan bukan merupakan dzat yang esa. Pemahaman lain pun puncul ketika anak dengan hambatan pendengaran mendeskripsikan Nabi Muhammad SAW. Dikarenakan nama Nabi Muhammad SAW sering muncul disetiap ada nama Alloh SWT, mereka berfikir bahwa Nabi Muhammad SAW adalah istri dari Alloh SWT. Pemikiran tersebut menunjukkan bahwa konsep Nabi dan Rasul belum dapat mereka fahami.

Pentingnya sebuah pengkajian dan pengembangan terkait pendekatan pembelajaran dalam pendidikan agama bagi anak berkebutuhan khusus termasuk di dalamnya anak dengan hambatan pendengaran. (Rohmah, 2010, hlm. 10). Pendidikan agama Islam yang diselenggarakan dari masjid ke masjid yang tersebar di beberapa kota di Indonesia seperti Yogyakarta, Surakarta, Semarang, Bnadung dan Jakarta merupakan salah satu kegiatan keagamaan yang memberikan pembinaan agama bagi penyandang hambatan pendengaran. Peserta dengan hambatan pendengaran memperoleh penyesuaian pendidikan agama termasuk kesempatan kepada mereka untuk menyampaikan kembali materi keagamaan yang telah mereka dapat di depan umum dengan bahasa isyarat, tentunya dengan seorang penerjemah yang membantu menterjemahkan kembali ke bahasa lisan.

Salah satu tempat diselenggarakanya pendidikan agama Islam bagi anak dengan hambatan pendengaran yang masih berjalan sampai dengan saat ini adalah Masjid Khoiru Ummah Semarang. Kegiatan pendidikan keagamaan tersebut dilaksanakan bagi anak dengan hambatan pendengaran yang beragama Islam dengan bersama jamaah masjid lain secara inklusif. Anak dengan hambatan pendengaran usia sekolah (SMP dan SMA) yang berjumlah kurang lebih 30 orang rutin mengikuti program pendidikan agama Islam di masjid ini. Berbeda dengan kegiatan serupa di kota lain yang diikuti hanya belasan penyandang hambatan pendengaran dengan rentang usia dewasa. Dikarenakan jumlahnya anak dengan hambatan pendengaran cukup banyak dari setiap kegiatan yang rutin dilangsungkan, mereka sering berbagi pengalaman dengan mengadakan kunjungan dan pelatihan ke daerah maupun kota lain.

Berangkat dari pembahasan tersebut, peneliti tertarik untuk mengkaji lebih jauh pendidikan Agama Islam bagi anak dengan hambatan pendengaran di Masjid Khoiru Ummah Semarang melalui sebuah penelitian kualitatif deskriptif. Peneliti ingin mendeskripsikan secara komprehensif bagaimanakah pelaksanaan pendidikan agama Islam yang diselenggarakan bagi anak dengan hambatan pendengaran yang berlangsung secara inklusif dan non formal di Masjid Khoiru Ummah Semarang, sehingga akan diperoleh gambaran mengapa pesertanya yang terhambat dalam mendengar bukan hanya faham materi dan pesan keagamaan yang disampaikan namun juga memiliki kesadaran diri untuk menunaikan kewajiaban mereka sebagai umat beragama (Religious Practice) serta mampu menyampaikan ajaran agama kepada kepada masyarakat (Religious Knowledge and Religious Effect).

Penelitian ini dibatasi pada kegiatan pendidikan agama Islam yang lebih difokuskan pada kegiatan bimbingan dengan sistem non formal sebagai jalur pelaksanaanya. Sistem non formal dalam pendidikan agama Islam bagi anak dengan hamnbatan pendengaran ini salah satunya ditunjukkan dengan fleksibelnya program evaluasi yang dilakukan. Evaluasi pada kegiatan pendidikan agama Islam ini tidak dilakukan secara tertulis ataupun tes, tetapi lebih ditekankan pada penguasaan Religious Practice dan Religious Effect sebagai sebuah kompetensi yang dimiliki anak dengan hambatan pendengaran setelah mengikuti program pendidikan. Pelaksanaan pendidikan dalam penelitian ini pun tidak ditentukan selama kurun waktu tertentu namun lebih bersifat sukarela bagi para pesertanya mengikuti setiap program yang diselenggarakan.

\section{METODE}

Penelitian ini menggunakan pendekatan kualitatif dengan desain studi kasus untuk mengetahui pelaksanaan pendidikan agama Islam bagi anak dengan hambatan pendengaran di Masjid Khoiru Ummah Semarang. Melalui pendekatan tersebut dimaksudkan agar dapat diperoleh deskripsi secara komprehensif untuk mengetahui pelaksanaan pendidikan agama Islam bagi anak dengan hambatan 


\title{
J PK (J urnal Pendidikan Khusus), 16 (1), 2020 - 22
}

\author{
Bayu Pamungkas, Zaenal Alimin
}

pendengaran di Masjid Khoiru Ummah Semarang yang berlangsung pada jalur non formal dalam sebuah setting inklusif.

Tahapan dalam penelitian ini terdiri dari penentuan subjek penelitian, pengumpulan data penelitian, dan analisis data hasil penelitian yang telah diperoleh. Subjek penelitian ini adalah tiga pembimbing anak dengan hambatan pendengaran sebagai informan utama dan tiga anak dengan hambatan pendengaran sebagai informan pendukung. Kedua informan dipilih agar diperoleh data dari seluruh pelaku pendidikan agama Islam bagi anak dengan hambatan pendengaran di Masjid kHoiru Ummah sehingga data penelitian lengkap dan komprehensif.

Pengumpulan data penelitian dilakukan dengan teknik observasi partisipatif dan wawancara semi terstruktur, serta studi dokumentasi terkait pendidikan agama Islam bagi anak dengan hambatan pendengaran yang dilaksanakan. Kemudian dilakukan uji kredibilitas data menggunakan member check untuk mengetahui kredibilitas data yang diberikan oleh informan penelitian (Sugiyono, 2013, hlm. 276).

Dalam penelitian ini digunakan teknik analitical induction untuk menganailis data. Langkahlangkah yang dilakukan yakni dengan mereduksi data, menyajikan data (display data) dan meanrik kesimpulan (konklusi) dan verifikasi (Creswell, 2008, hlm. 244). Berikut adalah proses analisis data dalam penelitian ini:

Reduksi Data; data hasil wawancara dari informan penelitian (tiga pembimbing anak dengan hambatan pendengaran dan tiga anak dengan hambatan pendengaran) dieeduksikan dan dilakukan pengkodean. Selain itu data hasil observasi diulas dalam catatan lapangan.

Penyajian Data; dalam proses proses penyajian data, data-data terkait pelaksanaan pendidikan agama Islam bagi anak dengan hambatan pendengaran di Masjid Khoiru Ummah Semarang yang telah terhimpun disajikan secara naratif dalam pemaparan hasil setelah sebelumnya dikelompokkan dalam kategori tertentu sesuai dengan fokus penelitian.

Penarikan Kesimpulan atau Verifikasi; setelah dianalisis dalam tahap pengumpulan data, selanjutnya dilakukan proses penarikan kesimpulan dilakukan penjelasan perspektif peneliti tentang pelaksanaan pendidikan agama Islam bagi anak dengan hambatan pendengaran di Masid Khoiru Ummah Semarang. Kesimpulan yang didapatkan tersebut menjadi hasil dalam penelitian ini.

\section{HASIL DAN PEMBAHASAN}

Berikut adalah hasil dan pembahasan hasil penelitian berupa uraian dan analisis yang mendeskripsikan pelaksanaan pendidikan agama Islam bagi anak dengan hambatan pendengaran di Masjid Khoiru Ummah Semarang terkait (1) Proses Pendidikan, (2) Pengaturan Tempat dan Waktu (3) Profil Anak dengan Hambatan Pendengaran (4) Profil Pembimbing Anak dengan Hambatan Pendengaran (5) Hasil Pendidikan.

Proses Pendidikan: Dalam rangka pelaksanaan pendidikan agama Islam bagi anak dengan hambatan pendengaran, terdapat beberapa kegiatan yang terdiri dari kegiatan ibadah yang bersifat personal dan 5 kegiatan utama yang terbagi dalam dalam program harian, program mingguan, serta program bulanan program bulanan. Kegiatan-kegiatan tersebut meliputi kegiatan musyawarah, silahturahmi (jaulah), ta'lim, mudzakaroh, dan ceramah (bayan).

Berikut penjelasan tentang program-program tersebut: (a) Kegiatan musyawarah yang dilakukan dalam program harian dan bulanan dalam pendidikan agama bagi anak dengan hambatan pendengaran tersebut membantu anak dengan hambatan pendengaran termotivasi berkomunikasi dengan masyarakat umum serta berani menyampaikan pendapatnya; (b) Kegiatan silahturahmi (jaulah), kegiatan ini dimaksudkan agar anak dengan hambatan pendengaran terlatih berinteraksi dalam masyarakat umum.; (c) Kegiatan ta'lim, berisi pembacaan hadist-hadist tentang keutamaan / keuntungan beramal dimaksudkan untuk menambah semangat anak dengan hambatan pendengaran dalam beramal agama; (d) kegiatan mudzakaroh bertujuan agar anak dengan hambatan pendengaran dapat belajar mengamalkan sunah Nabi Muhammad SAW dalam kehidupan sehari-hari; dan (e) pada kegiatan ceramah (bayan), dimaksudkan agar anak dengan hambatan pendengaran berani dan mampu menyampaikan kembali apa yang telah mereka pelajari selama program pendidikan agama Islam berlangsung.

Dalam hasil penelitian ini diketahui bahwa materi yang diajarkan dalam pendidikan agama Islam bagi anak dengan hambatan pendengaran yang diselenggarkan di Masjid Khoiru Ummah Semarang khususnya dalam kegiatan ta'lim dan mudzakaroh meliputi penyederhanaan tata cara ibadah 


\title{
J PK (J urnal Pendidikan Khusus), 16 (1), 2020 - 23
}

\author{
Bayu Pamungkas, Zaenal Alimin
}

dan tata cara hidup sesuai dengan yang diajarkan sunah Nabi Muhammad SAW. Selain itu juga terdapat materi berupa inti dari hadist-hadist Nabi Muhammad SAW yang disingkat dan disederhanakan. Proses penyederhanaan tersebut bukan pada hadistnya secara langsung (matan hadist) yang telah mutlak dan tidak dapat diubah, namun lebih pada substansi hadist dengan tujuan untuk menyesuaikan dan memudahkan anak dengan hambatan pendengaran yang notabene mengalami hambatan dan keterbatasan bahasa dan akan mengalami kesulitan untuk mempelajari hadist-hadist dengan kalimat yang panjang dan bahasa yang kompleks. Hal tersebut sesuai dengan hasil penelitian Soliha (2010, hlm. 12) yang menyatakan bahwa anak dengan hambatan pendengaran cenderung menggunakan bahasa yang pendek dan sederhana dalam tulisan, serta sedikit meggunakan kata-kata.

Temuan penelitian ini juga menunjukkan bahwa dari kelima kegiatan tersebut, selain kegiatan ta'lim dan mudzakaroh yang berisi pembahasan materi keagamaan, bentuk kegiatan lain yakni kegiatan musyawarah, silahturahmi (jaulah) dan ceramah (bayan) yang dilaksanakan pada pendidikan agama Islam bagi anak dengan hambatan pendengaran di Masjid Khoiru Ummah Semarang menunjukkan sebagai suatu kegiatan yang telah dirancang agar anak dengan hambatan pendengaran dapat meningkatkan kemampuan bersosialisasi dengan masyarakat umum. Dengan intensitas berinteraksi dan berkomunikasi yang sering dengan masyarakat umum pada kegiatan musyawarah, silahturahmi (jaulah) dan ceramah (bayan) tersebut maka anak dengan hambatan pendengaran dapat mengoptimalkan keterampilan sosialnya. Temuan penelitian ini diperkuat oleh pendapat Tarsidi (2002, hlm. 22) yang menjelaskan bahwa dimulainya perkembangan kompetensi sosial pada anak terjadi pada awal kehidupannya, kompetensi sosial tersebut sangat dipengaruhi oleh interaksinya anak dengan orang-orang terdekat dalam lingkungannya., baik lingkungan keluarga maupun lingkungan sosial yang lebih luas.

Senada dengan hal tersebut, Utami (2014, hlm.1) menjelaskan bahwa anak yang mengalami kehilangan kemampuan mendengar, mereka kurang bahkan tidak memiliki akses terhadap bunyi bahasa yang tumbuh dan berkembang di lingkunganya, anak dengan hambatan pendengaran kurang memperoleh kesemapatan berinteraksi dengan lingkungan. Hal tersebut mempengaruhi perkembangan bahasa mereka khususnya bahasa lisabn. Kemampuan berbahasa merek tidak berkembang dengan baik seperti anak pada umumnya, dikarenakan perkembangan keterampilan berbahasa sangat dipengaruhi oleh perolehan akses bahasa dan interaksi dengan lingkungan. keterampilan berbahasa sejatinya dapat berkembang apabila mereka memiliki akses terhadap sejumlah besar bahasa yang tumbuh dan berkembang di lingkungan.

Krathwohl, Bloom dan Masin (Cartledge \& Milburn: 1993, hlm. 19) menjelaskan bahwa salah satu dimensi kognitif dalam keterampilan sosial adalah persepsi sosial. Persepsi sosial merupakan dimensi kognitif yang ditandai dengan kemampuan individu untuk menerima dan mengukur situasi yang terjadi di sekitarnya serta kemampuan individu untuk menentukan perilaku yang sesuai dengan respon terhadap perilaku orang lain. Sesuai dengan teori tersebut, temuan penelitian ini menunjukkan bahwa pada kegiatan silahturahmi (jaulah) yang dilakukan dengan berkunjung ke rumah warga sekitar masjid tempat iktikaf untuk belajar menyampaikan agama, anak dengan hambatan pendenaran juga dilatih agar mereka dapat meningkatkan keterampilan sosialnya baik dalam dimensi afektif maupun dalam dimensi kognitif dengan cara menghadapi dan memahami berbagai keberagaman ekspresi perasaan dari warga yang dikunjungi, karena tidak semua warga yang dikunjungi menunjukkan perasaan senang dan menerima kunjungan dari mereka.

Pada pelaskanaan pendidikan agama Islam bagi anak anak dengan hambatan pendengaran di Masjid Khoiru Ummah Semarang, secara umum bahasa yang paling sering digunakan untuk proses pendidikan adalah Bahasa Isyarat Indonesia (BISINDO). Namun hal tersebut tidak menutup kemungkinan digunakannya bahasa oral pada kesempatan-kesempatan tertentu. Dapat dikatakan penggunaan Komunikasi Total dengan memanfaatkan berbagai spektrum berbahasa yang ada diterapkan selama proses pendidikan. Komunikasi total yang digunakan untuk berkomunikasi dengan anak dengan hambatan pendengaran dijelaskan oleh Garreston dalam Bunawan (1997, hlm. 26) yang menyatakan bahwa komunikasi total tidak adanya pembatasan dalam kesempatan berkomunikasi. Makna komunikasi total sesungguhnya bukan merupakan suatu metode melainkan suatu falsafah tentang komunikasi.

Metode yang pembimbing gunakan dalam pendidikan agama Islam bagi anak dengan hambatan pendengaran di Masjid Khoiru Ummah Semarang dalah Metode Contextual Teaching and Learning. Metode ini dipilih agar anak dengan hambatan pendengaran dapat lebih belajar secara nyata dan dapat 


\title{
J PK (J urnal Pendidikan Khusus), 16 (1), 2020 - 24
}

\author{
Bayu Pamungkas, Zaenal Alimin
}

terlatih mempraktekkan materi-materi keagamaan yang diajarkan. Hal tersebut sesuai dengan penjelasan Depdikanas (2003, hlm. 3) yang menjelaskan bahwa dengan Contextual Teaching and Learning / pembelajaran kontekstual menekankan materi ajar tidak hanya dihafal namun harus dibangun (konstruktif). Dalam hal ini anak harus membangun pengetahuan-pengetahuan mereka menjadi sebuah pengetahuan yang utuh dan tidak terpisah, selanjutnya pengetahuan utuh tersebut dapat mencerminkan sebuah keterampilan.

Pengaturan Tempat dan Waktu: Semua kelainan berbahasa dan berbicara berpotensi untuk mengisolasi orang-orang yang menyandangnya. Smith (2006, hlm. 213-214) menjelaskan bahwa hambatan komunikasi yang dialami seorang siswa dapat berdampak serius bagi kehidupan pendidikan dan sosialnya. Diperlukan cara yang dapat mempermudah siswa dengan hambatan komunikasi untuk membantu mencapai keberhasilan pendidikan. Upaya yang dilakukan pembimbing anak dengan hambatan pendengaran di Masjid Khoiru Ummah Semarang untuk membantu keberhasilan program pendidikan agama Islam bagi anak dengan hambatan pendengaran adalah dengan melakukan berbagai variasi setting kegiatan pendidikan yang meliputi penyesuaian pengaturan tempat dan waktu kegiatan. Penyesuaian tersebut didasarkan pada aktivitas program dan materi yang diajarkan.

Temuan dalam penelitian ini juga menunjukkan bahwa ketiga sistem pengaturan tempat dan waktu dalam pendidikan agama Islam bagi anak dengan hambatan pendengaran tersebut mengadopsi dari 3 model pendidikan inklusi yakni model kelas regular, model kluster dan pull out. Manik (2011, hlm 37) menjelaskan bahwa model kelas reguler, model kluster dan sistem pull out. Dalam hal ini anak berkebutuhan khusus belajar bersama dengan anak lain yang tidak berkebutuhan khusus dalam sebuah kelas regular dan dalam dsebuah kelompok khusus, kemudian dalam waktu-waktu tertentu anak tersebut memperoleh pembelajaran individual di ruang sumber bersama dengan guru pembimbing khusus.

Di Masjid Khoiru Ummah Semarang, anak dengan hambatan pendengaran belajar bersama dalam 1 kelompok/ majelis dengan jamaah umum pada kegiatan menyajikan materi-materi sederhana dan tidak terlalu kompleks serta masih dapat diidyaratkan secara langsung oleh penterjemah. Kegiatan tersebut antara lain kegiatan musyawarah, mudzakaroh / pembahasan fiqih sederhana dan jaulah / berkeliling silahturahmi.

Ketika penterjemah tidak memungkinkan untuk mengisyaratkan materi secara langsung dikarenakan materi cukup kompleks misalnay pada kegiatan ta'lim dan bayan / ceramah, anak dengan hambatan pendengaran ditempatkan dalam 1 majelis / kelompok tersendiri secara terpisah dari jamaah umum namun asih dengan materi yang sama dengan penyederhanaan yang disesuaikan.

Dalam kegiatan mudzakaroh khusus, diperlukan waktu yang lebih khusus antara pembimbing dan anak dengan hambatan pendengaran. Kegiatan mudzakaroh khusus dilaksanakan secara private dan intensif yang dilaksanakan sebelum program iktikaf dan di sela-sela program yang lain. Pada kegiatan ini dibahas materi-materi keagamaan yang belum dimengerti sepenuhnya oleh anak, perseiapan materi berceramah serta pemberian motivasi agar anak dengan hambatan pendengaran memiliki kefahaman terhadap manfaat dari program-program yang diikutinya dan memiliki semangat serta kepercaaan diri mengikuti berbagai program lain khususnya yang berhubungan dengan masyarakat umum.

Profil Anak dengan Hambatan Pendengaran: Anak dengan hambatan pendengaran peserta pendidikan agama Islam di Masjid Khoiru Ummah Semarang berada pada rentang usia remaja yang duduk di bangku sekolah menengah (SMP dan SMA). Dikarenakan berada pada rentang usia yang sama maka mereka belajar secara bersama tanpa pengelompokkan. Di usia yang sudah mulai masuk pada fase dewasa (baligh) yang rentan terhadap pengaruh negatif, usia remaja sangat memerlukan pengarahan dan pembimbingan keagamaan.

Dikarenakan anak dengan hambatan pendengaran peserta pendidikan berada di rentang usia remaja yang akrab dengan kehidupan sosial dengan teman sebaya, sering kali mereka mengajak teman mereka untuk bersama-sama hadir di Masjid Khoiru Ummah Semarang untuk belajar agama. Fenomena tersebut sejalan dengan pendapat Smith (2006, hlm. 287) yang menjelaskan bahwa kesulitan yang dialami individu dengan hambatan pendengaran dalam menjalin dan mempertahankan hubungan dengan orang yang tidak mengalami gangguan pendengaran mungkin menjadi penyebab utama adanya kecenderungan mereka untuk berkelompok dengan sesama penyandang hambatan pendengaran yang disebut "Colonis of Deafness". 
Komunikasi dengan orang tua anak dengan hambatan pendengaran peserta pelatihan dilakukan oleh pembimbing agar tercipta sinergi, dukungan dan kerjasama diantara keduanya. Anak dengan hambatan pendengaran sangat terbantu dengan kesederhanaan materi dan metode serta setting yang bervariatif selama pelaksanan pendidkan. Selain itu di sana mereka dapat menemukan komunitas yang dapat memfasilitasi mereka.

Anak dengan hambatan pendengaran yang mengikuti pendidikan agama Islam di Masjid Khoiru Ummah Semarang menunjukkan antusiame mengikuti setiap program pendidikan. Hal tersebut ditunjukkan dengan mereka selalu meluangkan waktunya di sela-sela rutinitas dan kegiatan mereka. Anak dengan hambatan pendengaran peserta pendidikan menujukkan kebaghagiaan dan ketenangan.selama mengikuti proses pendidikan.

Profil Pembimbing Anak dengan Hambatan Pendengaran: Pembimbing anak dengan hambatan pendengaran pada pendidikan agama Islam di Masjid Khoiru Ummah Semarang memiliki keanggotaan yang bersifat sukarela. Untuk menjadi pembimbing bagi anak dengan hambatan pendengaran tidak dilakukan proses penseleksian. Dalam hal ini pembimbing bagi anak dengan hambatan pendengaran berasal dari masyarakat yang sukarela ingin membantu anak dengan hambatan pendengaran belajar agama. Selanjutnya masyarakat tersebut yang akan diberdayakan sebagai pembimbing. Untuk membekali para pembimbing anak dengan hambatan pendengaran diadakan pelatihan intensif selama beberapa hari bagi pembimbing anak dengan hambatan pendengaran agar mereka semakin termotivasi membimbing anak dengan hambatan pendengaran, memiliki kompetensi yang lebih dan dapat berperan aktif dalam setiap program pendidikan yang telah disusun.

Pembimbing anak dengan hambatan pendengaran memperoleh pelatihan bahasa isyarat sebagai pelatihan pertama mereka. Materi pelatihan dimulai dengan pelatihan Bahasa Isyarat dasar yakni pelatihan huruf abjad dan kosakata sederhana dalam Bahasa Isyarat. Materi huruf abjad dan kosakata sederhana dipilih dikarenakan kedua materi tersebut merupakan sebuah unsur pokok untuk menjalin komunikasi dengan anak dengan hambatan pendengaran. Hasil penelitian tersebut sesuai dengan penelitian Wendawati (2012, hlm 49) yang menjelaskan bahwa salah satu syarat utama dalam keterampilan berbahasa adalah penguasaan kosakata, artinya seseorang akan semakin mudah menyampaikan dan menerima informasi (lisan, tulisan dan tanda-tanda isyarat) jika ia terampil berbahasa.

Para pembimbing anak dengan hambatan pendengaran memperoleh pengalaman tersendiri selama membimbing anak anak dengan hambatan pendengaran mengikuti setiap program pendidikan. Mereka merasakan kebahagiaan melihat anak dengan hambatan pendengaran yang dibimbingnya menjadi individu yang taat dan memiliki kepedulian terhadap orang lain. Pembimbing anak dengan hambatan pendengaran berharap pembimbingan mereka dapat menjadi amal kebaikan di akhirat nanti. Mereka juga berharap agar lebih banyak lagi yang tergerak hatinya bersedia menjadi pembimbing bagi anak dengan hambatan pendengaran untuk belajar agama.

Hasil Pendidikan: Glock \& Stark dalam Ancok (2005) menjelaskan dalam diri seseorang teraktualisasi 5 dimensi religiusitas. Kelima dimensi yang dimaksud yakni Religious Belief, Religious Practice, Religious Feeling, Religious Knowledge dan Religious Effect. Temuan penelitian ini menunjukkan bahwa terdapat lima dimensi religiusitas yang teraktualisasi dari diri anak anak dengan hambatan pendengaran yang peserta pendidikan di Masjid Khoiru Ummah Semarang.

Berbagai kegiatan yang dilakukan dan materi yang disampaikan pada kegiatan iktikaf yang diselenggarakan sebagai program bulanan dalam rangka pendidikan agama Islam bagi anak dengan hambatan pendengaran di Masjid Khoiru Ummah Semarang secara keseluruhan bertujuan untuk memberikan kefahaman kepada anak dengan hambatan pendengaran tentang pentingnya nilai iman dan amal agama, selain itu juga bertujuan untuk menanamkan ke dalam diri anak dengan hambatan pendengaran tentang pentingnya berdakwah, memikirkan saudara muslim yang lain dan berusaha untuk mengajak mereka baik sesama anak dengan hambatan pendengaran maupun orang mampu dengar disekitarnya agar bersama-sama mengusahakan iman dan amal. Kemampuan anak dengan hambatan pendengaran berceramah di depan jamaah umum hanya merupakan hasil tambahan dan sebagai media bagi mereka untuk berbagi fikir terhadap saudara muslim yang lain, bukan merupakan tujuan akhir dari pendidikan agama Islam yang berpusat di Masjid Khoiru Ummah Semarang tersebut.

Secara umum hasil pendidikan agama Islam bagi anak dengan hambatan pendengaran di Masjid Khoiru Ummah Semarang yang diperoleh dalam penelitian ini adalah bahwa anak dengan hambatan pendengaran peserta pendidikan menunjukkan ketaatan dalam beribadah khususnya sholat. Mereka 
dapat menjaga sholat wajib berjamaah secara tepat waktu. Dalam kehidupan bermasyarakat, anak dengan hambatan pendengaran peserta pendidikan memiliki kepercayaan diri untuk bersosialisasi dan berceramah di depan masyarakat umum.

Dalam penelitian ini juga ditemukan bahwa pada kegiatan iktikaf sebagai sebuah program bulanan, berbagai program dan materi yang disampaikan berbagai kegiatan yang dilakukan dan materi yang disampaikan secara umum bertujuan untuk memberikan pemahaman kepada anak dengan hambatan pendengaran terkait esensi penting dari nilai iman dan amal agama, serta menanamkan pentingnya mereka berdakwah, berbagi fikir dan kerisauan terhadap saudara muslim yang lain dengan berusaha untuk mengajak masyarakat baik yang mengalami hambatan pendengaran maupun orang mampu dengar disekitarnya untuk bersama-sama belajar iman dan amal.

Kemampuan anak dengan hambatan pendengaran berceramah di depan umum bukan merupakan tujuan utama dan tujuan akhir dari pendidikan agama Islam yang dilaksanakan, namun hal tersebut adalah hasil tambahan media bagi mereka untuk berbagi kefahaman dan fikir terhadap sesame individu muslim yang lain.

Secara ilustratif, hubungan antar temuan penelitian ini dilihat pada "Gambar 1. Hubungan Temuan Penelitian” berikut ini

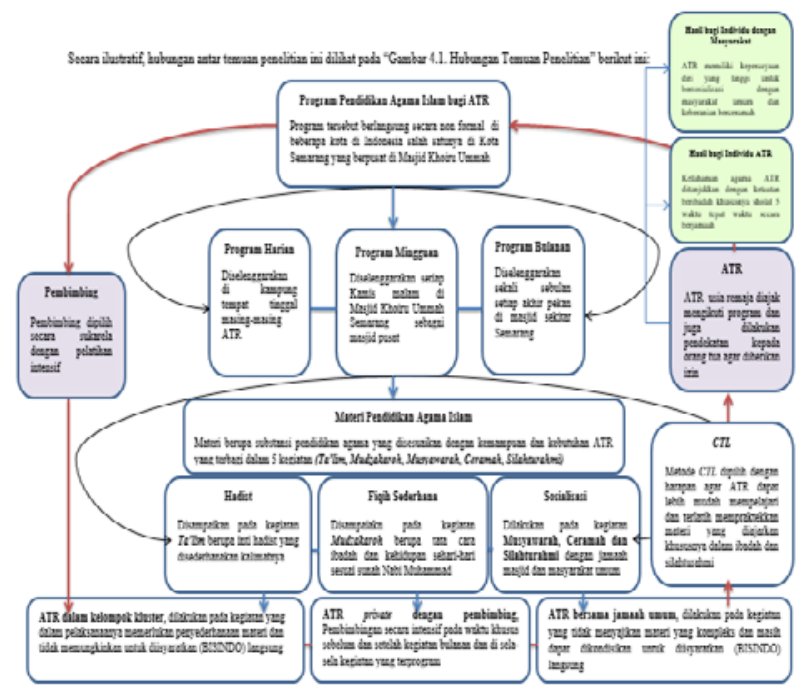

Gambar 1. Hubungan Temuan Penelitian

\section{SIMPULAN}

Berdasarkan hasil penelitian, berikut adalah simpulan yang dapat ditarik terkait pelaksanaan pendidikan agama Islam bagi anak dengan hambatan pendengaran yang berlangsung secara non formal dalam setting inklusif di Masjid Khoiru Ummah Semarang:

Proses Pendidikan: (1) Terdapat lima kegiatan dalam rangka pendidikan agama Islam dengan keterlibatan masyarakat dalam proses pelaksanaanya, merupakan hal yang positif jika anak dengan hambatan pendengaran belajar agama Islam bersama masyarakat umum; penggunaan Bahasa Isyarat Indonesia (BISINDO) sebagai sistem komunikasi utama selain penggunaan Komunikasi Total; digunakanya Metode Contextual Teaching and Learning dalam pelaksanaanya; materi disesuaikan bagi anak dengan hambatan pendengaran (tidak keseluruhan materi pendidikan agama Islam diajarkan). Pengaturan Tempat dan Waktu: (2) Terdapat tiga setting tempat dan pembagian waktu terkait kompleksitas materi dan teknis pengisyaratan. Profil Anak dengan Hambatan Pendengaran: (3) Anak dengan hambatan pendengaran peserta pendidikan agama Islam tersebut adalah anak dengan hambatan pendengaran usia remaja yang kemudian mengajak temanya yg lain dan membentuk "Colonies of Deafness". Profil Pembimbing Anak dengan Hambatan Pendengaran: (4) Pembimbing anak dengan hambatan penddengaran adalah masyarakat yang diberdayakan, mereka yang secara sukarela bersedia membantu anak dengan hambatan pendengaran belajar agama yang selanjutnya mengikuti proses pelatihan intensif. Hasil Pendidikan: (5) Anak dengan hambatan pendengaran yang mengikuti pendidikan agama tersebut memiliki kefahaman beragama, ketaatan dalam beribadah dan hubungan bermasyarakat yang baik. 


\section{J PK (J urnal Pendidikan Khusus), 16 (1), 2020 - 27}

Bayu Pamungkas, Zaenal Alimin

\section{DAFTAR PUSTAKA}

Ancok, D. 2005. Psikologi Islami. Yogyakarta: Pustaka Pelajar

Bunawan, Lani. 1997. Komunikasi Total. Jakarta: Depdikbud

Cartledge, G. \& Milburn (1993). Teaching Social Skill to Children. New York: Pergamon Press.

Creswell, J. W. 2008. Educational Research - Planning, Conducting, And Evaluating Quantitative And Qualitative Research. Third Edition. New Jersey: Pearson Education, Inc

Depdiknas. 2003. Pendekatan Konstektual, tentang Contextual Teaching And Learning. Depdiknas

Manik, Z.S. (2011). Pendidikan Inklusif. Diperoleh 11 Maret 2013, dari http://www.google.com/pendidikan/inklusif/presentation-transkrip

Rohmah, S. M. 2010. Pendidikan Agama Islam Dalam Setting Pendidikan Inklusi. Jakarta: UIN Syarif Hidayatullah. Thesis

Smith, J. D. 2006. Inklusi, Sekolah Ramah untuk Semua. Bandung: Nuansa

Soliha, Eli. 2012. Penggunaan Media Kartu Huruf Hijaiyah dalam Meningkatkan Kemampuan Membaca Iqro Jilid 1 Pada Anak Tunarungu. Diperoleh 15 November 2014 dari www.repository.upi.edu

Somantri, Sutjiihati. 2007. Psikologi Anak Luar Biasa. Bandung: PT. Refika Aditama

Subakti. 2011. Implementasi Pendidikan Agama Islam di SD Islam Terpadu (Studi Deskriptif pada SD Plus Islam Terpadu Bhaskara Sukamelang Subang). Jurnal Pendidikan Forum Tarbiyah

Sunarti, E. 2012. Model Pembinaan Keagamaan di Masyarakat Melalui Majelis Taklim (Studi Kasus di Majelis Taklim Miftahussa'dah Cianjur). Bandung: Universitas Pendidikan Indonesia. Skripsi

Sugiyono. 2013. Metode Penelitian Pendidikan Pendekatan Kuantitatif, Kualitatif, dan R\&D. Bandung : Alfabeta

Tarsidi, Didi. 2002. Kompetensi Sosial Anak Tunanetra. Bandung: Universitas Pendidikan Indonesia. Thesis

Undang-Undang Republik Indonesia No. 20 tahun 2003 Tentang Sistem Pendidikan Nasional. Jakarta: Depdiknas

Utami, Y.T. 2014. Sikap Siswa Tunarungu Terhadap SIBI (Sistem Isyarat Bahasa Indonesia) di SLB B Kota Bandung. Universitas Pendidikan Indonesia. Thesis

Wendawati, W. N. Program Pembelajaran Kosa Kata melalui Pendekatan Kontekstual bagi Siswa Tunarungu Kelas II SDLB B Di SLB N Subang. Bandung: Universitas Pendidikan Indonesia. Thesis

Wibowo, A. M. 2011. Pelaksanaan Pendidikan Agama Islam Pada Sekolah Luar Biasa di Propinsi Bali. Jurnal Pendidikan Forum Tarbiyah

\section{PROFIL SINGKAT}

Bayu Pamungkas, anak kelima dari lima bersaudara, lahir di Sukoharjo, Jawa Tengah, pada 5 November 1990. Pendidikan untuk tingkat Sekolah Dasar (SD) ditempuh di SDN Kusumodilagan Surakarta dan Sekolah Menengah Pertama (SMP) di SMPN 19 Surakarta. Untuk tingkat Sekolah Menengah Atas (SMA) ditempuhnya di SMAN 4 Surakarta. Setelah menyelesaikan program Strata 1 nya pada Pendidikan Luar Biasa (PLB) di Universitas Sebelas Maret, Surakarta, Jawa Tengah (20092013) ia kemudian melanjutkan pendidikanya pada program Magister Pendidikan Khusus (PKh) di Universitas Pendidikan Indonesia, Bandung, Jawa Barat dan selesai pada tahun 2015. Selanjutnya ditahun yang sama ia bekerja sebagai dosen di Universitas PGRI Yogyakarta (UPY) pada Program Studi Pendidikan Luar Biasa (PLB) sampai tahun 2018, kemudian ia melanjutnya karirnya sebagai dosen Pendidikan Luar Biasa (PLB) Universitas Negeri Yogyakarta (UNY) sampai dengan saat ini. 